\title{
MONGOLIAN URBAN GAMES
}

\author{
Tamás CSORNAI-KOVÁCS \\ Department of Inner-Asian Studies, Eötvös Loránd University \\ H-1052 Budapest, Pesti Barnabás u. 1, Hungary
}

\section{SOCIAL BACKGROUND}

Game has easily adjusted itself and the pattern shown in everyday life to the tempo dictated by the life cycle of the Mongols, who are nowadays still nomadising and live on the steppes. Through the playful mechanisms of copying children could unperceptibly learn the hardest works around the house (yurt), that were necessary for the existence. In case of nomadic peoples the exact border between game and work became blurred: it is easy to change from work to play and vice-versa. ${ }^{1}$

From the 30s and 40s of this century the comfort, jobs and possibility of career offered by the cities started a migration process. One may think that this course of events may separate the city and the countryside. Unpredictably this relationship not merely on economical soil - is detectable in the survival and transformation of cults, religious and magical beliefs. Applying these facts for my essay means, that most of the games used by shepherds are in use even in the cities; there are only a few original urban games. It is not my aim to set a new category, but to introduce those games I have got acquainted with during my trips in Mongolia in 1995-1996 and those which seemed to be the most popular ones from the discussions with my informants.

After the disappearing of a certain role of 'Cultural Gate' played by the Chinese (until 1921) and the late Soviet Union (1924-1989), America and Japan with their cultural influence are starting to fill this space, nevertheless games and toys coming from these parts of the world are not commonly spread due to the lack of solvent demand. As a result of the above mentioned causes people are obliged to turn back to their well proved national games (shagai, ${ }^{2}$ playcard, chess) or to the self-made and newly invented ones.

It is quite understandable that it belongs to our time's sad reality to see many children not playing at all. For a lot of them have to perform more serious duties even at the age of 5-6, - especially in summer-time, when the tourist season begins helping to earn the living of the family. In order to do that they are forced to spend part of the day with casual work. These works are frequently done with no adult

${ }^{1}$ S. SzYNKIEwICZ: Sport und Spiele in: W. HeISSIG: Die Mongolen. Frankfurt am Main, 1989, pp. 205-215.

${ }^{2}$ A knucklebone (med.: os malleolare) game, known as astragalus. 
supervision which may offer a variety of lonely and collective, playful (and competitive) working activities, e. g. shoeblacking, selling juniper seed, books or refreshment. In such situations inventiveness and rapidity are the most important factors; they call the attention of people by loud shouting. ${ }^{3}$ With no set working hours they have the chance to draw back and play in the shade: the most courageous ones may risk even their money on hazardous games (aziin togloom), they bet (mörii tawix) in order to have the bigger prize (xonjwor or xojwor), so that they may stop working for the rest of the day.

\section{FUNCTION OF GAME}

It is significant to declare that for nomadic peoples, game also used to have other functions, than enjoyment, but these functions are vanishing. The case of dolls (xӥ̈̈xeldei) proves this item well: dolls, human shaped figures were taboos (ceer) because of their supernatural attributes. It is a well known fact that many or knucklebone games played by Mongols had magical importance, games meant benefits for those taking part in them, e. g. at lunar New Year's (Cagaan Sar) second of third day, when participants believed that the game would bring them good fortune and good progeny for the forthcoming year. ${ }^{4}$ The 'Spotted Turtle' (alag melxii) game ${ }^{5}$ has the function of fortunetelling (šagaigaar mergelex). Particular games were practised in order to develop aiming ability for bow and arrow, e. g. 'Bull-shooting' (bux buu$d a x)^{6}$ or 'Shagai arrow' (šagai xarwax) $)^{7}$ the description of which can be found as 'Bone arrowing play's in Hungarian special literature. Unlike in KABZINSKASTAWARZ's and SZINKIEWICZ's divisions in my opinion it is important to emphasise that the range 'Three games of men' (Eriin gurwan naadam or shortly Naadam) held annually either nation-wide or regionally on 11-13th of July with other games is a simplification of the facts. Though the name of the feast originated from the verb 'to play' (naada-) the three events: wrestling (böx barildax), horse-racing (morinii uraldaan), archery (sur xarwax) became rather a sport ${ }^{9}-$ it is well known that it was practised as a military exercise and muster in ancient times - than a game.

${ }^{3}$ undaa awaarai, samar awaarai (soft drink, please; juniper seed, please).

${ }^{4}$ I. KABZINSKA-STAWARZ: Games of Mongolian Shepherds. Warsaw, 1991, p. 17.

5 YA. CEWEL: Mongol xelnii towč tailbar toli (Explanatory Dictionary of Mongolian Language) Ulan Bator, 1966, p. 355. I. KABZINSKA-STAWARZ: ibid. pp. 21-24, p. 119.

${ }^{6}$ O. FARKAS: Mongol csigacsont játékok (Mongolian knucklebone games) in: Keletkutatás, Autumn 1987, p. 57.

${ }^{7}$ G. SÜXBAATAR: Darigangiin xü̈̈xdiin togloom. (Dariganga children games) Ulan Bator, 1962. p. 5. I. KABZINSKA-STAWARZ: ibid. p. 132. K. U. KÖHALMI: A steppék nomádja lóháton, fegyverben (Nomad of steppes on horseback, in arms). Budapest, 1972. p. 94. M. TATÁR: Egy mongol bokacsontjáték (A Mongolian Knucklebone Game) in: Keletkutatás. 1973. p. 99.

8 A. LUKÁCSY: Népek játékai (Games of Nations). Budapest, 1981. (1964), p. 269.

${ }^{9}$ Apart from its game-like character, for competitors it is surely a real profession; many of them put their lives on preparing themselves with the help of a coach (zasuul) to win appreciation and respect by getting different titles. The cultic functions nowadays are disappearing e. g. traditional wrestlers (böx) also act as judoists or sport-wrestlers. 
The games related with sagai, domino (daaluu) checkers (xölögt togloom $)^{10}-$ being less common in cities - are outside the scope of my investigation. I have to notice that though šagai is easily available (people usually play it after meals), its pieces are often replaced by stones, coins, etc. applying the same rules.

\section{MONEY GAMES}

We can distinguish between two types of money games: one played with coins $(z o o s)^{11}$, and the other with notes (caas or möngön temdeg)..$^{12}$ People are out to win money of course: each of the participants have to invest the same sum, the one that gives the money with the biggest face value may start the game.

\section{COIN GAMES}

'Money tossing' (möngö xayax): it shows similarity with the 'Shagai throwing' $(\text { šagai šidex })^{13}$ game. Players have to toss up more and more coins and catch them with the back of the hand, and from that position to throw up again and catch them together with a flick. Another version based on this one is 'Moneying' (möngödöx), which needs two players and two coins. The players must carry out 6 determinate figures in quick succession. The one that makes a mistake - loses, and has to give another piece of coin to restart the game.

1. The name of the first figure is 'Milking Mare' or 'Milking Cow' (güü saax or ünee saax $),{ }^{14}$ which is also known from shagai games. At the first stage of this game the coins must be tossed up to the back of the hand, and from there out from the coins tossed up in the air again the one that is closer to the fingers must be caught, then the second one must be let to fall freely into the hand.

2. The B variant of 'Milking Mare' contains the same exercises but in reverse order (xoirdugaar gü̈̈ saax).

3. 'Knocking' (tonšilt) or 'Woodpecker' (tonšuul) is the name of the figure which is connected with the typical movement of the players. The coins tossed up from the

\footnotetext{
${ }^{10}$ N. NAMJILDORJ: Mongolin xölögt togloom (Mongolian board games). Ulan Bator, 1963. I. KABZINSKA-STAWARZ: ibid. pp. 28-43. A. POPOVA: Analyse formelle et classification des jeux de calculs mongols in: Etudes Mongoles, 1974/5. N. BASSANOFF: Les jeux des calculs mongols in: Etudes Mongoles, 1974/5. G. SÜXBAATAR: ibid. pp. 11-19.

${ }^{11}$ In 1911 the old manchu coins (soxor zoos) frequently used by fortune tellers, in 1990 the coins of the People's Republic (tögrög and möngö) were withdrawn from circulation. C. BATSAIXAN, G. TÖMÖRBAATAR, C. NINA: Mongol Ulsin möngön temdegt ba zoos (Mongolian National banknotes and coins). Ulan Bator, 1992.

12 The big sized (cca $200 \times 100 \mathrm{~mm}$ ) banknotes were withdrawn from circulation in 1966 . With the banknotes of the new series it is easier to play because of their smaller size. Presumably these years are the time of formation of this game.

${ }^{13}$ YA. CEWEL: ibid. p. 829. O. FARKAS: ibid. p. 57.

${ }^{14}$ I. KABZINSKA-STAWARZ: ibid. p. 21.
} 


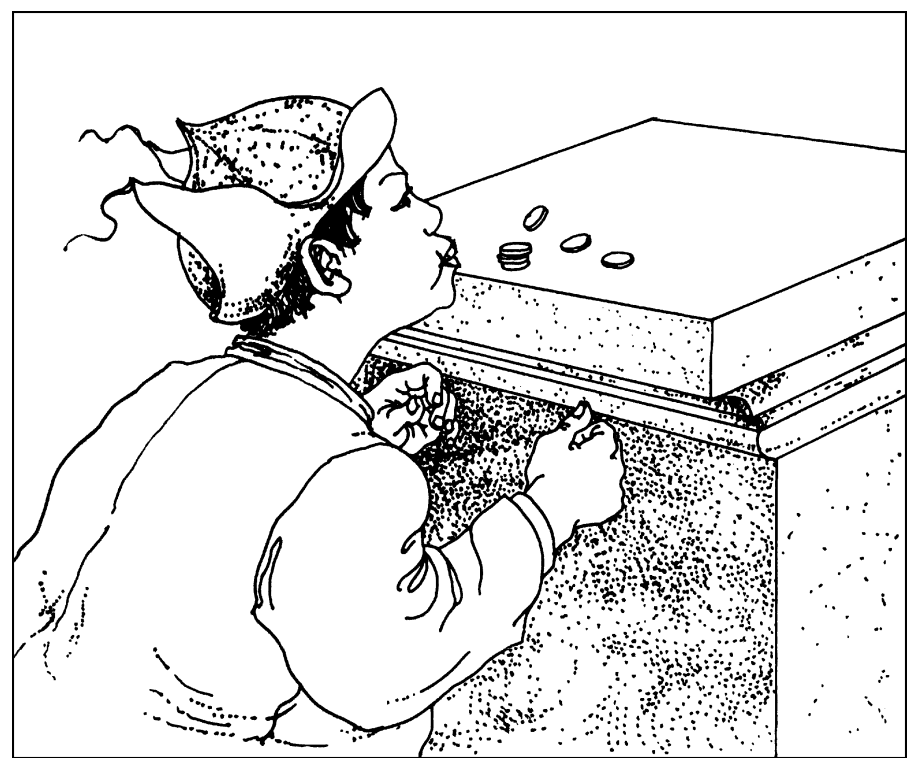

Fig. 1

back of the hand have to be caught one by one in quick succession with rapid flicks of the hand, that reminds one of the motion of knocking of woodpecker.

4. The $\mathrm{B}$ variant of this is a movement in reverse order (xoirdugaar tonšilt).

5. Doing the figure 'Elbow' (toxoi) players catch the coins placed on their elbow with one short flick.

6. 'Fruit Collecting' (jims tüüx) can be described as follows: one of the coins lying on the back of the hand must be allowed to fall on the ground and then to be picked up with the thumb and the forefinger - playing attention to the other piece still lying on the hand not to fall down - and tossed back on the hand.

Finished the procedure both coins tossed up from the back of the hand must be caught flying with a horizontal movement. The player, who makes all the figures continuously without making a mistake can keep the money of the other participants. In the children's version of this game stones or flattened aluminium caps of bottles (taglaa) substitute the coins.

'P-ing' (pedex) (Fig. 1): the name of this game is an onomatope, from the superposed money column given - in equal amounts - by the players (3-4 persons). As many as possible coins have to be blown off accompanied by a strong aspirated 'p' consonant. The coin fallen down with its national arms upside (böglöödöx süldeer buux) goes to the blower until money is left. Children play this game with caps of beer-bottles put one on another. The player hits the cap on top and the caps fallen down with illustration-side upside can be kept. The value of the caps depends on agreement, each has a different rate. The most valuable ones are white, called 'Armoured' (xuyagt) the less precious ones are the 'Soldier' (cereg). 
The game 'Hitting the Picture' (zurag coxix) can be found in KABZINSKA-STAWARZ's essay ${ }^{15}$ as well. The goal is to strike (bai onox) a cigarette-box (tamixin xair$c a g$ ) on the ice with a coin or a gravel. This may be a modern adaptation of an old game first mentioned in the 'Secret History of the Mongols' - 'Shooting a Knucklebone on Ice' (mösön šagai xarvax). ${ }^{16}$

\section{BANKNOTE GAMES}

Games like the previous ones are also played with banknotes. Players forming a hollow with their hand have to hit on the note with the portrait-side down and without touching it, only using the turbulence of the air, they have to turn it upside down. Children use sugar-paper (čixriin caas) - having one pictured side (zuragtai) - instead of notes. Loser's punishment (šitgel) is found out by the others. After finding out two ways of punishing they ask the loser which one he chooses. The loser does not know the difference between the choices. The punishment may be easier or harder depending on the choice of the loser from the alternatives offered by the winners. The following questions are asked: "Will you act like this or that way?" (Engex üü, tegex ü̈̈?). "How many times will you suffer the punishment? So much, or that much?" (Iim udaa, tiim udaa?).

\section{CHINESE STYLE FOOT-BADMINTON (TEVEG)}

This game has various names: 'Kicking the Teveg' (teveg öšiglöx), 'Play with Teveg' (teveg naadax), 'Teveging' (tevegdex). To prepare the plaything one piece of round $(2-2,5 \mathrm{~cm}$ in diameter) or square shaped $(2-2,5 \mathrm{~cm}$ lateral faced, $2-3 \mathrm{~mm}$ thick) lead, iron plate, or simply a coin ${ }^{17}$ is needed. The source of lead are usually run-down accumulators. After the shape of the base (taw) had been formed they drill two holes on it to fix the "feather of the toy" with a piece of brass-wire. Mongols use a flock of hair (tevegnii üs) instead of feather. It can be made either of horse's tail $^{18}$ (xyalgas) or unspinned smooth wool (naaluur) or even dog-fur ${ }^{19}$ (noxoin üs). The quality of the product determines the speed: it can be fast (xurdan) or slow (udaan) depending on the metal-fur balance. The main element of the game is proving one's quickness and skilfulness. The reward of the winner is nothing but appreciation. This game is often played by $4-5$ persons max. It is best to play it in boots because of its better surface, so players say. A player, that wears shoes, usually tucks his trousers' legs in the socks in order to develop sharpness. The aim is to keep

15 I. KABZINSKA-STAWARZ: ibid. p. 137.

16 Mongolok Titkos Története (The secret history of the Mongols) ed. L. LIGETI, Budapest, 1962. pp.

37-116. I. DE. RACHEWILTZ: Index to the secret history of the Mongols, Bloomington, 1972, p. 116.

17 I. KABZINSKA-STAWARZ: ibid. p. 135.

18 YA. CEWEL: ibid. p. 572.

19 G. SÜXBAATAR: ibid. p. 23. 


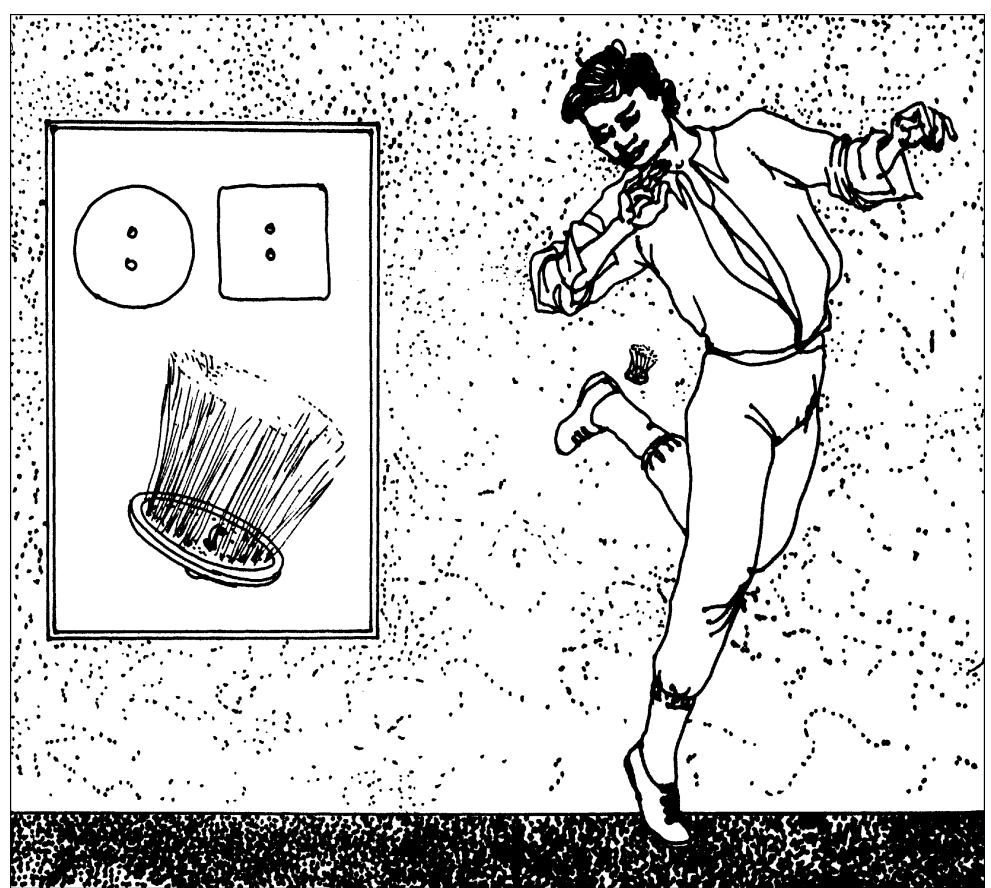

Fig. 2

the teveg in the air through different figures performed by the players. If the "ball" hits the ground a new competitor comes up. It is an important rule that the teveg must always fly vertically, high enough to have time for preparing the kicker leg. Just like in games for money different figures have to be shown in series, whilst others are counting the scores. The following rules are for right-legged persons. Each player starts his teveg kicking with his right leg in front (urdaa awax) while shouting the first syllable of the word 'proof' (ba-tal-gaa), then with the lateral part of the right shoe (xöliin araar awax) shouting the second syllable in parallel. At last the player kicks the teveg again from the front side shouting the last syllable. These spectacles are to prove the suitability of the contestant. Closing the performance the player kicks the teveg behind his left leg (ogcrox) (Fig. 2) and that time he may start the real series (toirog).

1. Players have to boot the teveg - in front - counting it paired (1-3-5...25), finishing the series with the right leg behind the left is necessary. Of this figure they play three rounds, one may perform the three rounds continuously if he makes no mistake. If the teveg falls down (gazart unax) the player must start from the beginning, but he has three ways to shorten the long process: a; point of shoe (gutalin xonšoor), b; changing the leg (solgoi xölööröö awax), c; kicking with knee (öwdög) at 15th or 17th score. After the three rounds the winner (the fastest or that with least mistakes) sets favourable conditions of a contract (tamga) to continue. 
2. At this part the kicking leg is not allowed to touch the ground, and players have to stock in one place making five boots in front, and one behind to close (no name mentioned).

3. Among the forthcoming figures there is a difference of difficulty stages. The 'Clean Five' (cewer taw) means one kick in front and five behind the left leg.

4. The 'Dirty Five' (boxir taw) contains boots behind and in front of the left leg. The erring (aldax hün) gives advance to the next rival by giving the chance to continue from his stage.

5. A configuration of three exercises comes last, that can be changed to one's taste: a: 'Crotch between the legs' (saltaa) - the teveg kicked by the right leg has to be kicked again by the other one, after crossing it with the right. b: 'Step' (rat) - with closed points of shoes the player shoots up the teveg so high to be able to cross his legs, which is the variant c: 'Foot-drop' (ölmii) - boot is done with the inner side of the clasped foot-drops.

6. 'To Catch or not to Catch' (awdag-awdaggüi) or 'Bow Legged' (mayga) - they play first with the right leg in front, then behind the left, and at last they catch the teveg with the left leg behind the right.

7. 'How much wins' (xojil xedeer) is about kicking teveg 15 times behind the left leg, if it falls down (even at the 14th score) one must start the section again. The one that makes the most scores above 15 may win if he absolves the 'batalgaa' criteria connected to the figure: after a kick with the right leg in front a left-leg kick behind the right leg, then a right-leg kick in front of the left. The whole series in finished by a back-boot to the player's taste.

Learning these games needs skills and incredibly hard work. The most qualified ones can perform 30 back-boots. I happened to hear about persons who were able to make it even 200 times $^{20}$ in front - this is the so called 'Jumping' (üsrex). Most of the players are boys at the age of 13-16. It was in vogue from the middle of 70's until the middle of 80's, especially in the September-October and spring period. There is opportunity for practising anytime (and anything can be used instead of appropriate teveg).

\section{HAND AND FINGER GAMES}

Games played with hands and fingers represent another main group. The first of its kind is the game hammer (alx)-paper (caas)-scissors (xaic)-stone (čuluu) well known in Europe as well, so it is unnecessary to explain the rules. The winner is who 'wraps up', 'nicks', 'cuts' or 'breaks' the rival.

The 'Earth to Sky' (gazar tengerdex) or 'Earth looks at its Sky' (gazar tengeree üzex) is played by at least four children, Adults play it to settle a question (e. g. who goes to buy alcohol?). The rule is simple: players hold their hands on the top of the

\footnotetext{
${ }^{20}$ This kind of activity may cause harm to the liver (böörönd тии) - so Mongols say.
} 
head and after counting three everybody shows his palm or back of hand depending on his will. They play until there will be someone (loser) who is left to himself.

In the game 'Middle Finger' (dundax huruu) or 'Finding the Middle Finger' (dund huruu olox) there's only a couple playing. Winner is that finds more times the hidden middle finger among the specially clasped fingers of the other's.

The 'Fingering' (huruudax) or 'Put out the Fingers' (huruu gargax) is where two players whip out their fingers of the right (proper) hand (zöw gar) suddenly, simultaneously shouting 'gee-up' $(\check{c} u)^{21}$, to give rhythm to the game. The one that has shown stronger finger (which is worth more) wins. There is fix value-scale of fingers: little finger (č̈gčii) $<$ ring finger (yadam) $<$ middle finger (dund huruu) $<$ forefinger (doloowor) $<$ thumb (erxii) $<$ littler finger, etc. Between the two fingers that are in play there cannot be any gap (e. g. the game is cancelled if a player shows his thumb and the other his middle finger, and they have to show their fingers again). Scores are counted on the left hand so after winning 4 times the counting fingers are sprung (cacax) indicating the end of the actual round. A game contains five rounds.

This game has an expanded variant called 'Dembee' (the name has Tibetan origin) or 'Singing Finger-guessing' (duutai huruu taalcax). During the communist era it was prohibited because of its gambling characteristics (möriitei togloom) and because the loser had to drink a considerable quantity of alcohol. ${ }^{22}$ 'The task is to guess the sum of fingers shown at the same moment by the participants. Before they say a number the players say: dembee - riddle, then they say the expected sum and show their hands. The players usually do not only say a number, but also describe it further, e. g. by using comparisons" ${ }^{23}$. These comparisons or adjectives are the 'Jewelwords' (čimeg üg) with which text (dembeenii üg) can be ornamented (čimeg ügeer bayajuulax). The text begins with the question: 'Can you play Dembee?' (Dembee medex ü̈̈ či?) or 'Silk-wrapped Value' (dencü̈ütei wandan) and is continued as follows: 0 - 'Close the Fist' (adgaj boox); 1 - 'Lonely Thumb' (erxii ganciin) or 'One of the Five' (tawiin ganc)*, 2 - 'Related Couple' (xolboo xoir), 3 - 'Exhausted Three' (gundaj guraw) or 'Sprinkling Three' (cacal guraw)*, 4 - 'Reluctant Four' (döngöö-, döngöj döröw) or 'Wandan's Four' (Wandan döröw)*, 5 - 'Peaceful Five' (tawlag taw) or 'Steppe Five' (taliin taw)*, 6 - 'Drawn Six' (zurmal zurgaa) or 'A Hundredth of Six' (zuutal zurgaa)*, 7 - 'Weak Seven' (doloo doroo) or 'Seven with Jug' (dombootai-, dombon-doloo)*, 8 - 'Friends Eight' (naiziin naim) or 'Interlaced Eight' (süljee naim)*, 9 - 'Ironic Blue' (egöötei cenxer) or 'Nine like a Hook' (degee yüs)*, 10 - 'Nice of Ten' (arwiin saixan) 'Full Ten' (delger araw)* ${ }^{24}$ Participants sing these special texts to the tune of a common folk song, which may differ regionally.

\footnotetext{
${ }^{21}$ It is noteworthy that these goading words are in use not only while riding a horse, but even in games. The rythm of the fast variant of game 'Dembee' is similar to galloping so it is called šogšix.

${ }^{22}$ This game was played mainly in the koumiss (airag) season. If there is koumiss enough the loser has to drink a big cup (xul) of it (1-3 litres). The description of this game is also available in: L. LIGETI: Sárga istenek, sárga emberek (Yellows Gods, Yellow People), Budapest, 1988. pp. 181-183. I. KABZINSKA-STAWARZ: ibid. pp. 77-79, 123.

${ }^{23}$ I. KABZINSKA-STAWARZ: ibid. p. 77

${ }^{24}$ The words marked with * are from I. KABZINSKA-STAWARZ: ibid. p. 77.
} 
The two versions of my collection (Algermaa - female name - and Zadgai Cagaan Ü̈̈l - Unowned White Cloud) are sung not only in the Capital but even in Töw, Arxangai, Öwörxangai counties.

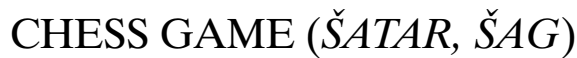

The rules are the same that are in use throughout the world, but I found a version showing similarity to a shangai game (see: bux buudax) called 'Acting like Ča-

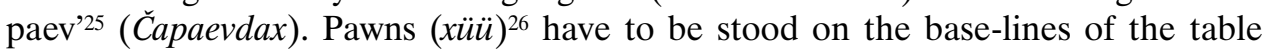
(šatriin xölög). The aim of the game is to hit the other's chessman with a piece of round plastic, or a wooden bullet (sum). The one with more chessmen left on the table (their position does not matter) wins the game.

\section{CARD (XÖZÖR) GAMES}

Mongols had their own cards from the earliest times, but no complete pack of cards remained. Nowadays they use European (especially French)-type cards with original rules. That is why only one game shows local, Buddhist marks (Fig. 3) of 'Black Jack': the '108-ing' (zuunnaimdax).$^{27}$ Players are on to reach this number by collecting cards. ${ }^{28}$ Knowing the terminology of chess and card games an unanswered question arises, namely: why Mongols do not title the most valuable character as King (xaan) instead of noyon? The probable answer may be found on the soil of taboos: the title of the majestic emperor must not be in use in everyday situations (e. g. in games).

The limits of extent and the games' diversity prevented us from making our list of urban games complete: lots of popular games exist, e. g. playing tag (čono tarwag bolox, or čono tarwagsax or cagaan temee), hide-and-seek (nuugdaj toglox), slingshooting (čawxaar-, xarwax), skipping rope (dees toglox), elastic rope (erzeen dees) (Fig. 4), drive a hoop (dugui türex) (Fig. 5), ball (bömbög), peashooting (guursaar carcaa alax), dice/dicing (šawga or šoo/šoodox), knife-throwing or conquering (delxiidex), fighting with matches (beldex), riddle (onisog). However, beside these, the most popular game - basketball (sags) - belongs to the sport categroy, as a result of

\footnotetext{
${ }^{25}$ A famous Russian officer.

${ }^{26}$ The figures are called bod except the King (noyon: Lord). Bods are the Castle (tereg: coach), Knight (mori: horse), Bishop (temee: camel or zaan: elephant), Queen (bers). Pawn may form kid, hunter, soldier, wrestler or hen and Queen may form dog, lion or tiger. Mongols call taking in chess 4 ways depending on what the victim is: taking (index) hüü - codlox, taking temee - duglax, taking mori - curax. Playing chess - šatar nü̈̈x, giving check - šaglax or šalax, mate - mad tawix or xojix, stalemate - goc mörgöx or xaincax, to castle one's King - selgex.

${ }^{27}$ The number 108 is a sacred one in the Lamaist religion.

${ }^{28}$ Playing cards - xözör tawix or xözör toglox, Hearts - bund, Spades - gem, Diamond - dörwöljin, Clubs - ceceg, Joker - xün, Ace - tamga, King - noyon, Queen - xatan, Young - bool, 10-4 on their numeral, 3 - dadar, 2 - tug.
} 


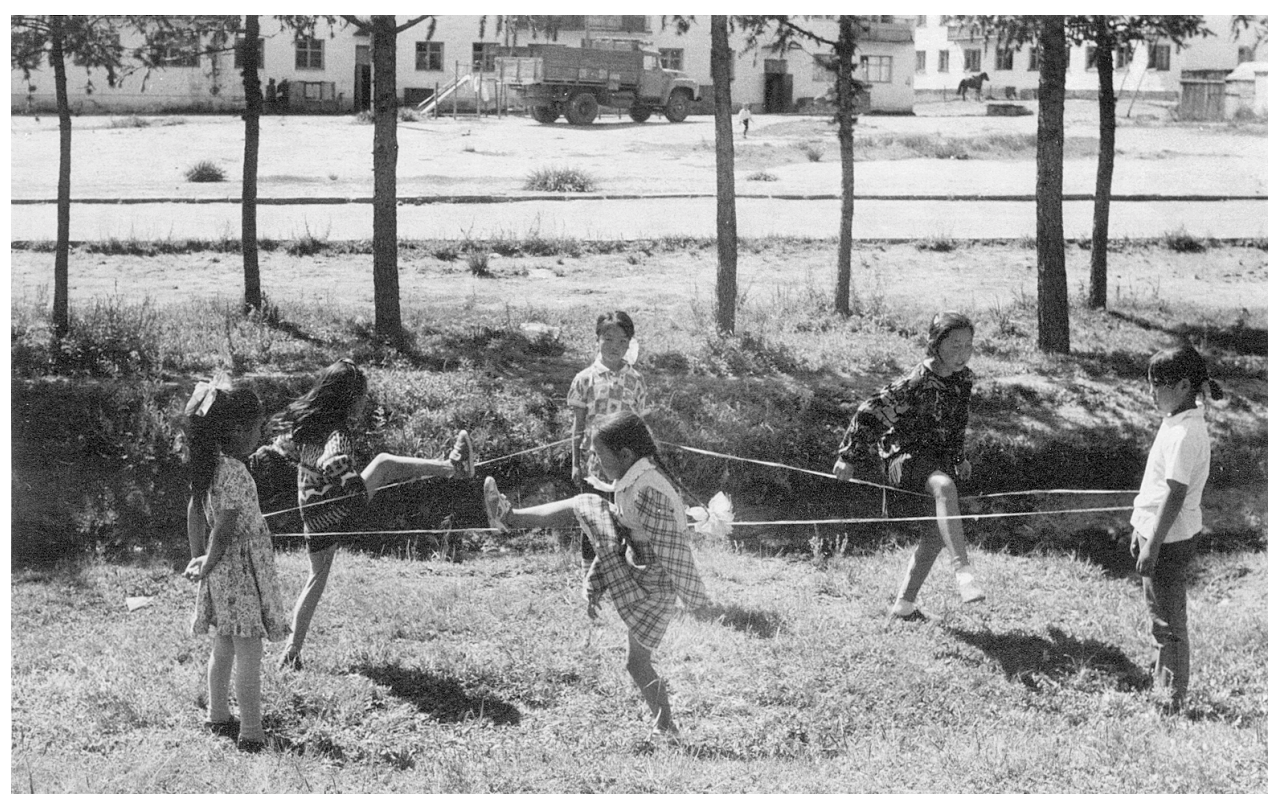

Fig. 3

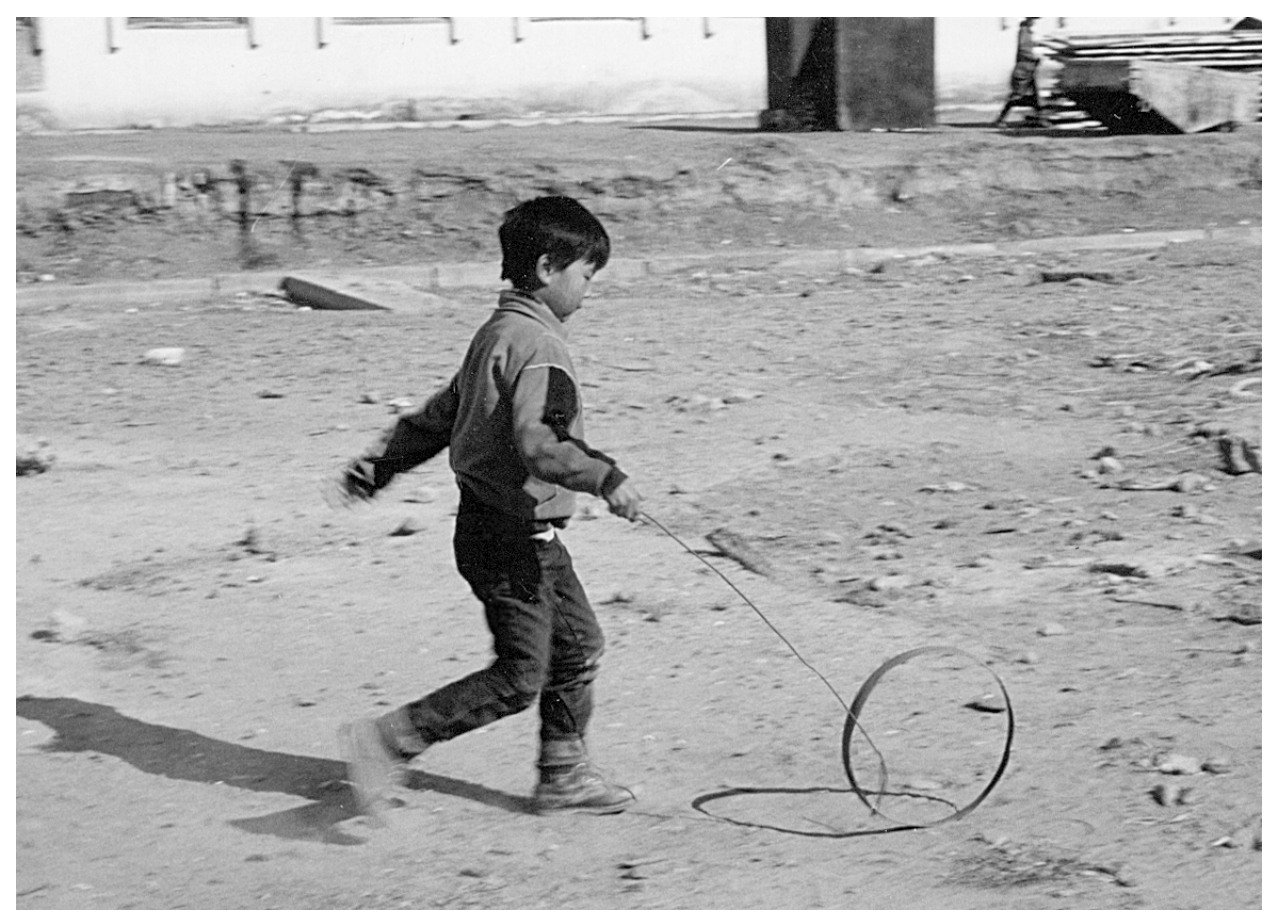

Fig. 4 


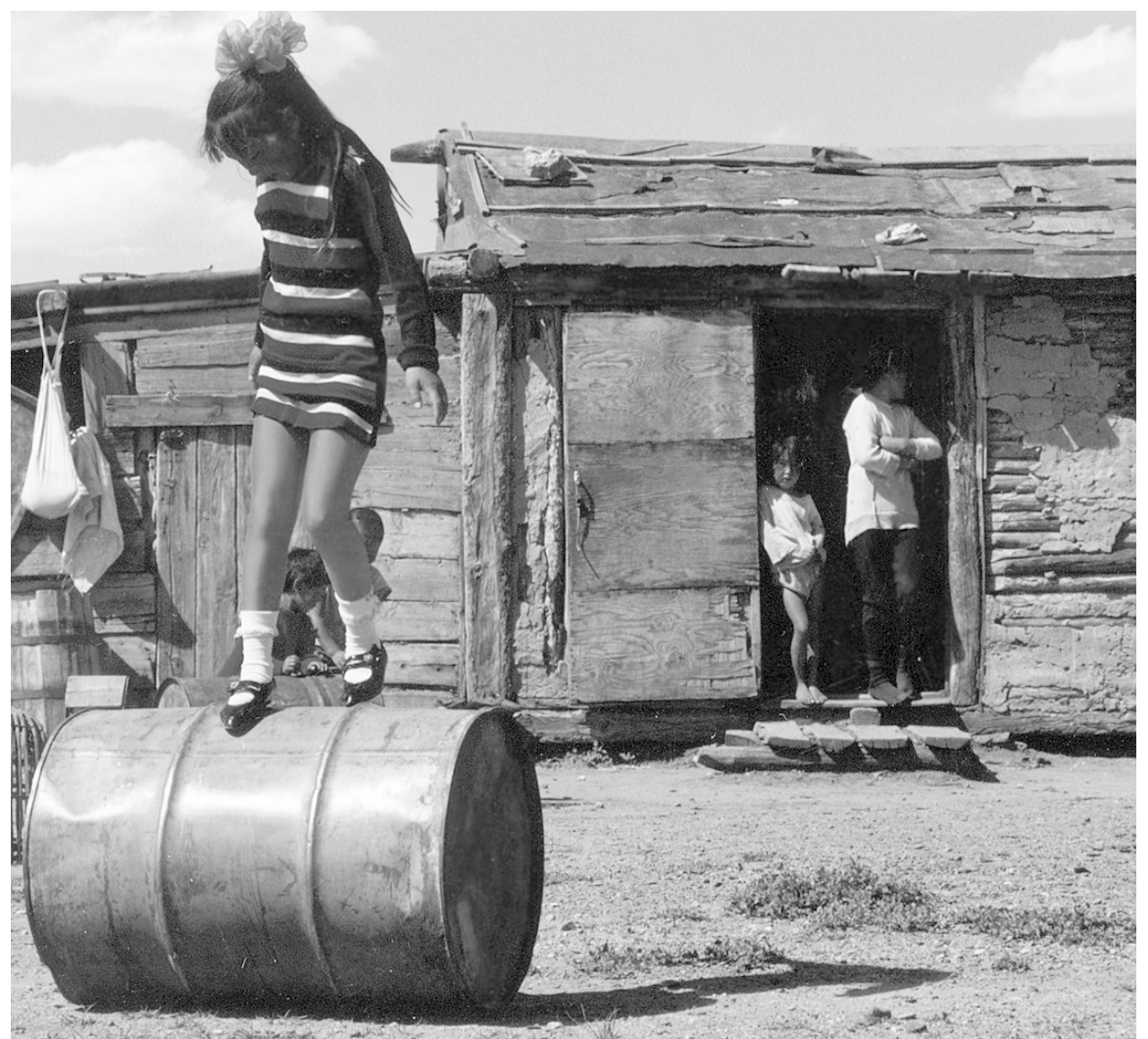

Fig. 5

American influence. The quick spread of this game is obvious even in monastery districts or yurt-courts, so it became a real street game just like streetball in the USA. The main consequence - considering all games - is the accidental nature of the objects of game (Fig. 6).

I wish to express my thanks to those who helped my work: the photos were taken by Ákos Bertalan Apatóczky (Figs. 3-4) and Zoltán Füredi (Fig. 5), Gabriella Maracskó (Fig. 1-2) has made the graphic illustrations. My master, Dr. Ágnes Birtalan, has served valuable advice. D. Ganbold and J. Selenge were helping me to choose and collect the appropriate terminology. 